Vol 21 No 1 Page 1-6, January 2021

\title{
The Influence of Chewing Habits on the Degree of Impacted Cerumen
}

Pengaruh Kebiasaan Mengunyah pada Derajat Sumbatan Cerumen

\author{
Asti Widuri \\ Universitas Muhammadiyah Yogyakarta
}

DATA OF ARTICLE:

Received: 17 Aug 2020

Reviewed: 17 Dec 2020

Revised: 03 Feb 2021

Accepted: 05 Feb 2021

*CORRESPONDENCE:

asti.widuri@umy.ac.id

DOI:

10.18196/mmjkk.v21i1.9576

TYPE OF ARTICLE:

Research

\begin{abstract}
Cerumen was glandular secretions at the outer one-third of the ear mixed with exfoliated squamous epithelium. The jaw's movement keeps the cerumen in the ear canal in a state of balance, so it is clean, protects and lubricates the external auditory canal. Impacted cerumen is also caused by excessive production, narrow canal anatomy, viscosity wax, and irritation due to cottontipped swabs habits. This study aims to determine whether chewing habits influence the degree of cerumen obstruction in patients with impacted cerumen. The study was a cross-sectional method in impacted cerumen patients at 17-80 years old in the ENT clinic of District Hospital Wates, Kulon Progo, Yogyakarta, Indonesia. Risk factors assessed were education, age, gender, chewing habits, and cotton-tipped swabs habits. The data were then analyzed by chi-square test. Of 80 respondents with the dominant age range $17-38$ years $(58.8 \%)$, the number of males was 47 (58.8\%), and females were 33 (41.2\%). The significant risk factors comprised the chewing habit and the use of cotton-tipped swabs. Factors affecting the degree of cerumen in patients with impacted cerumen were the chewing habits and cotton-tipped swabs habits.
\end{abstract}

Keywords: chewing habits; risk factor; impacted cerumen

\begin{abstract}
Abstrak: Cerumen adalah campuran sekresi kelenjar di liang telinga luar dengan epitel kulit yang terkelupas. Gerakan rahang saat mengunyah akan mendorong serumen sehingga jumlahnya seimbang dan berfungsi membersihkan, melindungi dan melumasi saluran telinga luar. Tersumbatnya serumen disebabkan produksi berlebih, saluran sempit, kekentalan dan pemakaian cotton bud. Tujuan penelitian ini untuk mengetahui pengaruh kebiasaan mengunyah dengan derajat sumbatan serumen. Metode penelitian potong lintang pada pasien sumbatan serumen usia 17 sampai 80 tahun di poliklinik RSUD Wates Kulon Progo Yogyakarta Indonesia. Variabel yang dinilai adalah Pendidikan, usia, jenis kelamin, kebiasaan mengunyah dan kebiasaan memakai cotton bud, kemudian dianalis dengan uji chi-square. Responden sebanyak 80 pasien sumbatan telinga kelompok usia terbanyak 17 sampai 38 tahun (58.8\%) jenis kelamin laki-laki 47 (58.8\% dan 33 (41.2\%) perempuan. Faktor risiko yang bermakna adalah kebiasaan mengunyah dan pemakaian cotton bud. Faktor yang mempengaruhi derajat sumbatan serumen adalah kebiasaan mengunyah dan pemakaian cotton bud.
\end{abstract}

Kata Kunci: kebiasaan mengunyah; factor risiko; sumbatan serumen 


\section{INTRODUCTION}

Cerumen is a natural product of the auditory canal. There are two types of cerumen: 1) Dry-type cerumen, the yellowish or gray color in brittle or hard form, and 2) Wet type cerumen, which is brown color, slippery, and sticky. The color can turn dark when exposed to free air. ${ }^{1}$ Cerumen can physiologically expel through natural jaw movement when talking and swallowing. Cerumen serves as the protection, canal lubricant, and transporting epithelial debris to prevent epidermal dryness. Excessive cerumen production can close the external auditory canal called cerumen prop, cerumen obscurant, or impacted cerumen. Cerumen impaction is potentially causing a feeling of fullness in the ear, conductive hearing loss, and disturbing view to examine the tympanic membrane.,

The process of excessive cerumen is influenced by the form of the narrow and winding ear canal, cerumen viscosity, repeated imitation due to the habit of cleaning the external auditory canal. ${ }^{2}$ In the elderly, cerumen tends to become drier due to the apocrine gland's physiological atrophy followed by a reduced component of sweat from the cerumen. Moreover, the excessive cerumen build-up for the elderly might not only caused by cerumen but also a pile of epithelial debris. Due to the narrowest ear canal in the middle ear, cotton swabs only push the cerumen farther into the isthmus, which is narrow and attached to the tympanic membrane. Consequently, the cerumen will be difficult to be moved. 3

On the other hand, chewing is a process of grinding and breaking down food into smaller pieces to become soft enough to swallow. Also, it aims to mix the food with saliva to stimulate taste buds. It stimulates the pleasant taste sensation and triggers the saliva secretion, pancreas stomach, and bile to receive the food. ${ }^{4}$ The chewing process can be involuntary, and most of the processes of chewing a meal are a rhythmic reflection of activation of skeletal muscles in the jaw, lips, cheeks, and tongue as the response of food pressure to the mouth tissues. Teeth can produce a greater pressure than needed to chew a meal. For example, molar for adults can produce a crushing force up to $100 \mathrm{~kg}$, which is enough to break hard grains. This force is usually not used. The degree of occlusion is more critical than biting strength in determining the efficiency of chewing. ${ }^{5}$

Additionally, modern people develop fast-eating behavior due to the limitation of getting enough time to eat. As a consequence, the habit of chewing the meal perfectly is ignored. It only increases the risk of cerumen builds up in the ear canal. Cerumen prop is commonly found by doctors, becoming comorbid in ENT, elderly, and mental retardation patients. ${ }^{5,6}$ Although cerumen prevalence rates have not been widely reported, according to Mahardika (2010), ${ }^{7}$ the incidence of cerumen obscurant in Semarang was 22.9\% (109 students) of 487 students examined. The symptoms of cerumen impaction, among others, are ear itching, pain, hearing loss, buzzing, dizziness, and an increased risk of infection; in severe cases, it causes deafness, less optimal work, and tympanic membrane perforation. ${ }^{8}$

The excessive cerumen production can close the external auditory canal, called the cerumen prop, ${ }^{9}$ caused by some factors. Firstly, the anatomy of the ear canal blocks the passage of the cerumen. Secondly, there is obscurant keratosis, an increase in keratin production that causes various symptoms, including necrosis of the cartilage canals, infection, and deafness. The third most common cause is a failure of keratinocyte separation that normally occurs in the outer ear canal as part of skin changes. Hard cerumen consists of dominant keratin sheets more than soft waxy liquid..$^{7,10}$

Previous research has reported that the cerumenolytic agents are commonly used to effectively dilute the cerumen and combine with irrigation to remove the impacted cerumen. However, the education to preventing the forming of cerumen with changing chewing habits is limited. Another preventive factor of cerumen impacted is to stop the use of cotton buds. Macknin (1994) ${ }^{11}$ reported that the occurrence of cerumen prop was $75 \%$ caused by using cotton buds. Clinicians should give education focusing on behaviors that promote safe and effective ear hygiene, such as good chewing habits and should not insert foreign bodies into the ear canal, including cotton buds and candles. This current study aimed to determine whether chewing habits influence the degree of cerumen obstruction in patients with impacted cerumen.

\section{MATERIALS AND METHOD}

The research design was an observational study with a cross-sectional method. The researcher assessed the relationship between the independent variable of chewing habit and the degree of cerumen by otoscopy examination. The research was conducted in District Hospital Wates, Kulon Progo, Yogyakarta, with the 
research subject of 80 patients diagnosed with a cerumen prop at 17-65 years old. The degree of cerumen prop depended on occlusion ear canal, classified into the grade of 0-4: (0) = there was no cerumen, (1) $=25 \%$ cerumen occlusion, (2) $=50 \%$ cerumen occlusion, $(3)=75 \%$ cerumen occlusion, and $(4)=100 \%$ cerumen occlusion. Furthermore, it was also categorized into two categories: a thick grade of 3-4 and a thin grade of 0-2. In this research, the sample of cerumen prop was obtained from both the left and right ears. ${ }^{12}$

The chewing habit was assessed by the amount of mouthfuls each person chewed using a hand counter. It was taken the average of three mouthfuls. During the probandus eating, the researcher paid attention to the way of chewing and measuring the amount of chewing with a hand counter. The chewing habit was divided into two categories: chewing less (<20 times) and good/normal chewing (20-33 times).

The data were then analyzed in the normality descriptively and using the chi-square test to analyze risk factors' influence by univariable analysis. The significant limitation was $p<0.05$, with a confidence interval of $95 \%$.

\section{RESULTS}

The respondent's characteristics can be seen in Table 1. The number of the respondents are 80 respondents with the highest number at the age group of 18-38 years old which is as many as 47 people (58.8\%). The lowest number is in the age group of 60-80 years old which is as many as eight people (10.0\%). The comparison based on gender is 47 men (58.8\%) and 33 people women (41.3\%). The majority educational background of the respondents is High School, which belongs to 38 respondents ( $47.5 \%$ and Elementary School which belongs to 11 respondents (13.8\%).

The effects of the chewing habit with the degree of cerumen prop can be seen in Table 2 . The result showed that chewing with the category of $<20$ chews with the thick cerumen degrees (grades $3-4$ ) occurred in 20 respondents (25.0\%). Meanwhile, the chewing habit with the Normal category (20-33 times) with a thin degree of cerumen (grade $0-2$ ) occurred in 29 respondents (36.2\%).

Table 1. The General Characteristics of the Respondents

\begin{tabular}{lcc}
\hline Characteristics & Total & Percentage \\
\hline Gender & 47 & $58.8 \%$ \\
Male & 33 & $41.2 \%$ \\
Female & & \\
Age & 47 & $58.8 \%$ \\
17-38 years old & 25 & $31.2 \%$ \\
39-59 years old & 8 & $10.0 \%$ \\
60-80 years old & & \\
Education & 11 & $13.7 \%$ \\
Primary school & 10 & $12.5 \%$ \\
Junior high School & 38 & $47.5 \%$ \\
Senior high School & 21 & $26.3 \%$ \\
College &
\end{tabular}


Table 2. The Analysis of Chewing Habit on the Cerumen

\begin{tabular}{|c|c|c|c|c|c|c|c|c|}
\hline \multirow{3}{*}{$\begin{array}{l}\text { Prop. Degree } \\
\text { Habits }\end{array}$} & \multicolumn{4}{|c|}{ Degre of cerumen } & \multicolumn{2}{|c|}{ Total } & \multirow[t]{3}{*}{$X^{2}$} & \multirow[t]{3}{*}{$\mathrm{p}$} \\
\hline & \multicolumn{2}{|c|}{ Thick } & \multicolumn{2}{|c|}{ Thin } & \multirow[b]{2}{*}{$\mathrm{n}$} & \multirow[b]{2}{*}{$\%$} & & \\
\hline & $\mathrm{n}$ & $\%$ & $\mathrm{n}$ & $\%$ & & & & \\
\hline$<20$ times & 20 & $25.0 \%$ & 13 & $16.3 \%$ & 33 & $41.3 \%$ & \multirow{3}{*}{3.869} & \multirow{3}{*}{0.049} \\
\hline 20-33 times & 18 & $22.5 \%$ & 29 & $36.2 \%$ & 47 & $58.7 \%$ & & \\
\hline Total & 38 & $47.5 \%$ & 42 & $52.5 \%$ & 80 & $100 \%$ & & \\
\hline
\end{tabular}

Table 3. The Influence of the Habit of Cleaning the Ears Using Cotton Buds on the Degree of Cerumen prop.

\begin{tabular}{|c|c|c|c|c|c|c|c|c|}
\hline \multirow{3}{*}{$\begin{array}{l}\text { Using Cotton } \\
\text { bud }\end{array}$} & \multicolumn{6}{|c|}{ Degree of Cerumen } & \multirow{3}{*}{$X^{2}$} & \multirow{3}{*}{$p$} \\
\hline & \multicolumn{2}{|c|}{ Thick } & \multicolumn{2}{|c|}{ Thin } & \multicolumn{2}{|c|}{ Total } & & \\
\hline & $\mathrm{n}$ & $\%$ & $\mathrm{n}$ & $\%$ & $\mathrm{n}$ & $\%$ & & \\
\hline No & 11 & $13.7 \%$ & 4 & $05.0 \%$ & 15 & $18.8 \%$ & & \\
\hline Yes & 27 & $33.8 \%$ & 38 & $47.5 \%$ & 65 & $81.2 \%$ & 4.941 & 0.026 \\
\hline Total & 38 & $47.5 \%$ & 42 & $52.5 \%$ & 80 & $100 \%$ & & \\
\hline
\end{tabular}

Based on the chi-square test (Table 3), the significant value of $p$-value is $0,049(p<0.05)$, thus it is proved that the habit of the chewing habit affects the risk of occurrence of cerumen prop. The influence of the habit of using cotton- bud as a tool to clean the ear is also reviewed in this study. The patients who clean his ear with cotton buds with the cerumen grade of + (grade 3-4) are 27 people (33.8\%). Meanwhile, the patients cleaning their ears by using cotton buds with cerumen grade of - (grade $0-2$ ) are 38 people (47.5\%). Based on the statistical counting, the significance value of $p$-value is $0.026(p<0.05)$. So, it can be said that the habit of cleaning the ears by using cotton buds influences the risk of having cerumen prop.

\section{DISCUSSION}

Cerumen production is a protective mechanism of the ear canal. However, cerumen should be removed when closed or totally blocked ear canal and causes symptoms, such as hearing loss, pain, tinnitus, and audiovestibular disorders. The results revealed that 80 respondents with cerumen in this research were mostly $17-$ 38 years old or in the productive age. This result differs from the previous report that geriatric and mental retardation are the most suffering cerumen prop. ${ }^{5}$ Probably, it was caused by the elderly population that suffered cerumen props who did not go to the doctor because of the asymptomatic of the cerumen symptoms due to their less social activities. The research at primary health care reported that $35 \%$ of elderly patients more than 65 years old suffered cerumen prop. ${ }^{13}$ The previous study also found that almost $40 \%$ of the homecare patients had cerumen prop. It was also reported the incidence of cerumen was $10 \%$ in children and $57 \%$ in the older patients in the home care but not influenced by using hearing aid. ${ }^{14,15}$

From otoscopic examination among kindergartens in Wuhan, the prevalence of cerumen impaction was higher than $10 \%$, and was more prone at children with dry cerumen, so annual examination was recommended. ${ }^{16}$ The incidence of cerumen prop based on gender was equal for males (47 people or $58.8 \%$ ) and females (33 people or $41.3 \%$ ). Thus, gender did not influence the occurrence of cerumen prop. It is in accordance with the research by Alriyanto (2010), ${ }^{17}$ which reported that the cerumen incidence was $12.1 \%$ in male students and $9.3 \%$ in female students. Probably, this research result was because there is no difference in the chemical process of forming the cerumen prop in men and women.

In this study, the habits, which were as risk factors of cerumen prop, were the chewing habits and lack of awareness to maintain ear hygiene. Therefore, the patients and the larger community can prevent and reduce the cerumen incidence by having a healthy lifestyle and avoiding the habit of chewing too fast. Because impacted cerumen is composed of abnormal exfoliated keratinocytes correlated with microbial induced neutrophil-mediated inflammation and mold infection, microbial removal is strongly 
recommended. ${ }^{10}$ Therefore, this preventive method using Boericke alcohol solution and miconazole ointment for the prevention of outer ear infections is recommended to general practitioners with less experience in differentiating pure cerumen from cerumen with fungal infections. ${ }^{18}$

The cerumen prop can cause hearing loss because it blocks the ear hole and disturbs the visualization of the tympanic membrane. The smaller the diameter of the ear canal, the greater the risk of cerumen prop. The ear canal's diameter has an essential role, and the normal ear canal diameter is about $0.9 \mathrm{~cm} .{ }^{5}$ This chewing level is defined as fast chewing or abnormal, which its frequency is less than 20 times, and normal chewing, which its frequency is about 20-33 times. Normal chewing tends to reduce the risk of the forming of cerumen prop. Previous research conducted by Dharmendra reported that the jaw movement system when chewing helps cleans the ear canal and moves out the cerumen that attaches to the ear canal wall. Experts say that chewing food properly also helps increase the number of nutrients get out from the food.

\section{CONCLUSION}

The habits of chewing food and cleaning the ears using cotton buds influences the degree of cerumen prop.

\section{ACKNOWLEDGEMENT}

The author kindly acknowledged to dr. Angga Putranto and dr. Sunaryanto Sp. THT who had provided patient data.

\section{CONFLICT OF INTEREST}

The author declared no potential conflicts of interest to the research and publication of this article.

\section{REFERENCES}

1. Schwartz SR, Magit AE, Rosenfeld RM, Ballachanda BB, Hackell JM, Krouse HJ, et al. Clinical Practice Guideline (Update): Earwax (Cerumen Impaction). American Academy of Otolaryngology-Head and Neck Surgery. 2016: p. 1-25. https://doi.org/10.1177/0194599816671491

2. Subha ST and Raman R. Role of Impacted Cerumen in Hearing Loss. Otorhinolaryngology. 2006; (9) 1: p. 23- 25.

3. McCarter DF, Courtney AU, and Pollart SM. Cerumen impaction. Am Fam Physician. 2007; 75: p. 1523-1530.

4. Astrand PO, and Rodahl K. Textbook of Work Physiology-Physiological Bases of Exercise $2^{\text {th }}$ ed. USA: McGrawHill Book Co. 2003

5. Lapeña JFF, and Edward A. External Auditory Canal Dimensions, Age and Cerumen Retention or Impaction in Persons with Down Syndrome. Annals of Otology, Rhinology \& Laryngology 2018: p. 1-5

6. Guest JF, Greener MJ, Robinson AC, and Smith AF. Impacted cerumen: composition, production, epidemiology, and management. QJM; 2004: p. 477-808. https://doi.org/10.1093/qjmed/hch082

7. Mahardika. Faktor-Faktor yang Mempengaruhi Pembentukan Serumen Obsturan (Studi Kasus pada Siswa SD Kelas V di Kota Semarang) 2010.

8. Burkhart CN, Kruge MA, Burkhart CG, and Black C. Cerumen composition by flash pyrolysis-gas chromatography/mass spectrometry. Otol Neurotol 2001; 22: 715-22. https://doi.org/10.1097/00129492-20011100000002

9. Karlsmose B, Lauritzen T, Engberg M, and Parving A. A randomized controlled trial of screening for adult hearing loss during preventive health checks. Br J Gen Pract 2001; 51: 351-5.

10. Zhang S, Jin M, Zhou G, and Zhang Y. Cerumen impaction was composed of abnormal exfoliation of keratinocytes that was correlated with infection Am J Otolaryngol. 2020; 41. https://doi.org/10.1016/j.amjoto.2019.102340

11. Macknin ML, Talo H, and Medendorp SV. Effect of cotton-tipped swab use on earwax occlusion. Clin Pediatrics1994; 33: p. 14-18. https://doi.org/10.1177/000992289403300103

12. Silverstein H, Wycherly BJ, and Alameda Y. A Prospective study to evaluate the efficacy of isopropyl alcohol irrigations to prevent cerumen impaction. Ear Nose Throat J. 2012; 91(3): p. 25-8. https://doi.org/10.1177/014556131209100318

13. Horton GA, Simpson MTW, Beyea MM, Beyea JA. Cerumen Management: An Updated Clinical Review and Evidence-Based Approach for Primary Care Physicians. Journal of Primary Care \& Community Health 2020; 11: p. 1-5. https://doi.org/10.1177/2150132720904181

14. Manchaiah V, Arthur J, Williams H. Does hearing aid use increase the likelihood of cerumen impaction? J Audiol Otol 2015; 19 (3): p. 168-71. https://doi.org/10.7874/jao.2015.19.3.168 
15. Roland PS, Smith TL, and Schwartz SR. Clinical Practice Guideline: Cerumen Impaction. Otolaringol Head and Neck Surg 2008; 139: p. 1-21. https://doi.org/10.1016/j.otohns.2008.06.026

16. Ping C, Yanling H, Youhua W, Shufen W, Zhinan W, and Zhongfang X. Epidemiology of cerumen impaction among municipal kindergartens children in Wuhan, China. Int J Pediatr Otorhinolaryngol 2017; 100: p. $154-6$. https://doi.org/10.1016/j.ijporl.2017.07.006

17. Alriyanto CY. Pengaruh cerumen obsturan terhadap gangguan pendengaran (Studi Kasus pada Siswa SD Kelas V di Kota Semarang) 2010.

18. Kiakojori K, Gooran AK, Rajabnia R, Mahdavi Omran S. A Study on the Effectiveness of Boericke Alcohol and Miconazole Ointment for the Prevention of Outer Ear Infections after Suction Clearance. J Babol Univ Med Sci. 2015; 17 (4): 29-35 